\title{
The Association Between -Market Risk Disclosure Reporting And Firm Risk: The Impact Of SEC FRR No. 48
}

Chen-Miao Lin, Clayton State University, USA

Wanda Lee Owens, Clark Atlanta University, USA

James E. Owers, Georgia State University, USA

\begin{abstract}
SEC FRR No. 48 requires that all firms report their market risk exposures using one or more of three alternative formats for disclosure: tabular format, sensitivity analysis, or Value at Risk (VaR). In this paper we examine how the method chosen affects a firm's risk as measured by total risk, the cost of equity, and firm specific risk. We find that firms using VaR have higher total risk and firm specific risk than firms using sensitivity analysis. Conversely, firms employing tabular disclosure generally have lower but not statistically significant lower total risk, cost of equity, and firm specific risk than firms using sensitivity.
\end{abstract}

Keywords: FRR No. 48, Risk disclosure, Firm risk

\section{INTRODUCTION}

乌

n January 1997, the Securities and Exchange Commission (SEC) issued Financial Reporting Release No. 48 (FRR No. 48), which required firms to disclose their quantitative market risk information relating to attributes such as interest rate risk, foreign currency risk, commodity risk, and other relevant market rate or price risk. The SEC provided three methodologies for disclosure of the information: tabular, sensitivity analysis, and Value at Risk (VaR). The requirement tries to make the firm's market risk exposures transparent to the investors. However, when choosing the method, a firm considers the benefits and costs of disclosure.

The potential benefits of risk disclosure are due to a reduction in asymmetric information. Myers and Majluf (1984) argue that the problem of asymmetric information between managers and shareholders leads firms to obtain external finance at a premium to compensate investors for the potential "lemons" problem. Asymmetric information also exacerbates the estimation error problem and the cost of equity as argued by Barry and Brown (1985), Coles and Loewenstein (1988), and Coles, Loewenstein, and Suay (1995). The basic argument is that for claimholders to estimate their required rates of return, they have to rely on some valuation models that are based on estimates of earnings and cash flows. However, parameter uncertainty coming from risk exposures of interest rates, exchange rates, and commodity prices leads claimholders to encounter some possible estimation errors. If estimation error is nondiversifiable, i.e. is systematic, reducing asymmetric information leads to a lower cost of equity.

However, the perceptions of the SEC disclosure requirements prior to the implementation of the ruling were that the disclosure would be costly, that the disclosure forces firms to divulge proprietary information to their competitors, and may lead other firms to stop hedging altogether. As General Motors put it, "If GM disclosed the volume of its commodity derivatives contracts and their anticipated cash flows, a competitor could calculate the purchase price of GM's components." (Wall Street Journal 6/25/1996).

In this paper, we examine the association between the method chosen for reporting market exposures and firm risk as measured by total risk, the cost of equity (systematic risk) and firm specific risk. Specifically, we examine whether one of the disclosure methods reveals more information to the market and thus reduces the firm's risk. 
We find that firms using VaR have higher total risk and firm specific risk, but the cost of equity is not greater than that for firms using sensitivity analysis. We also find that firms using VaR and other method(s) (76\% of the firms in this category choosing VaR and sensitivity) have higher total, cost of equity, and firm specific risk than firms choosing sensitivity analysis. This finding is supported by risk expert Leslie Rahl who stated "VaR is a single number as opposed to detailing your position, so you're (revealing) less to the competition" We also find firms that use tabular format generally have lower but insignificantly total, cost of equity, and firm specific risk than firms choosing sensitivity analysis. This is consistent with the comment letters sent to SEC that tabular format presents detailed and disaggregated information. Our results are summarized in Table 1.

Table 1 Summary of the Results

This table summarizes our main results. In this table, we compare the risk of a firm choosing tabular, VaR, and multiple methods to report its risk exposures with that of a firm choosing sensitivity. Risk is measured by total risk, cost of equity, and firmspecific risk. Total risk is the annualized standard deviation of daily stock returns multiplied by $252^{1 / 2}$. Cost of equity is measured by Fama and French three-factor and CAPM models. Firm specific risk is the annualized standard deviation of residuals from the Fama and French three-factor and CAPM models multiplied by $252^{1 / 2}$. Lower (higher) indicates the risk measure is lower (higher) than that of the firm choosing sensitivity.

\begin{tabular}{|c|c|c|c|}
\hline Method & & Risk & \\
\hline & Total Risk & Cost of equity & Firm Specific Risk \\
\hline VaR & Higher & Higher (insignificant) & Higher \\
\hline Tabular & Lower (insignificant) & Lower (insignificant) ${ }^{1}$ & Lower (insignificant) \\
\hline VaR and Other Method(s) & Higher & Higher $^{2}$ & Higher \\
\hline Sensitivity and Tabular & Higher (insignificant) & Lower (insignificant) ${ }^{3}$ & Higher (insignificant) \\
\hline
\end{tabular}

1. Higher but insignificant for the cost of equity estimated by CAPM.

2. Insignificant for the cost of equity estimated by CAPM.

3. Higher but insignificant for the cost of equity estimated by CAPM.

The paper is organized as follows: Section 2 discusses the Financial Reporting Release No. 48 disclosure requirements. Section 3 reviews the pertinent literature. The data and sample are described in section 4 and the methodologies employed in section 5. In section 6, the results of the empirical analysis are presented and interpreted. We conclude in section 7.

\section{FINANCIAL REPORTING RELEASE NO. 48 DISCLOSURE REQUIREMENTS}

As previously noted, financial Reporting Release No. 48 (FRR No. 48) requires firms to disclose their quantitative market risk information relating to attributes such as interest rate risk, foreign currency risk, commodity risk, and other relevant market rate or price risk by using one or more of three methodologies: tabular, sensitivity analysis, and Value at Risk (VaR).

The regulation requires firms choosing tabular methods to present information sufficient to allow investors to make estimates of the firm's market risk exposures. The information presented in the tabular format should include the market risk sensitive instruments' expected cash flows for each of the next five years, and the aggregate cash flows expected for the remaining years thereafter. Those using tabular format must also provide information on fair value and contract terms, such as notional amounts of derivatives, and weighted average interest rates of the market risk sensitive instruments. For example, Exhibit 1 shows Kroger's interest rate exposure in tabular format on its 10-K filing for fiscal year ended on January 29, 2005. For fixed and variable debt instruments, Kroger reported principal amounts and weighted average interest rates maturing from 2005 to 2009 and an aggregated total for all years after 2009. Kroger also reported fair value of its debt instruments at the fiscal year end. For interest rate swaps, Kroger reported the types of swaps (variable to fixed and fixed to variable swaps), notional amounts and weighted average pay and receive rates by expected maturity dates, and fair value.

Sensitivity analysis requires firms to expresses the potential loss in future earnings, fair values, or cash flows from selected hypothetical changes in market rates and prices. The regulation requires a firm choosing sensitivity analysis to provide a description of the model, assumptions, and parameters used to conduct sensitivity 
analysis. Exhibit 2 presents the sensitivity analysis reported by Best Buy on its 10-K filing for the fiscal year ending February 26, 2005. It reported that a one percentage point increase in interest rates would result in a $\$ 4$ million increase in interest expense.

Value at Risk (VaR) expresses the potential loss in future earnings, fair values, or cash flows from market movements over a selected period of time and with a selected likelihood of occurrence. A firm choosing VaR is required to report the model used e.g., variance/covariance, historical simulation, or Monte Carlo simulation and assumptions and parameters, e.g. holding periods and confidence intervals. Coca Cola is an example of a firm using VaR. On its 10-K filing for fiscal year ending December 31, 2004, it reported that it used a historical simulation model to compute the $\mathrm{VaR}$ and it was $95 \%$ certain that the maximum loss for the fair values of its foreign currency derivatives and other financial instruments for the next week would not exceed \$17 million, \$26 million, and \$34 million using 2004, 2003 or 2002 average fair values.

\section{LITERATURE REVIEW}

Guo (2003) looks at the effect of FRR. No. 48 on risk and the cost of capital in the debt market. Her research includes firms that chose $\mathrm{VaR}$ and sensitivity analysis for disclosure, and looks at whether the information content provided through the additional reporting requirements lead to lower default risk and cost of debt. Guo looks at 59 firms that issued new debt subsequent to providing risk disclosure information as mandated by FRR No. 48 and concludes that changes in bond default risk and cost of debt are negatively, but insignificantly, associated with market risk disclosure. Guo finds that firms choosing VaR for market risk disclosure have a significantly lower cost of debt and bond default risk than firms using sensitivity analysis, and firms that use hedging strategies effectively have lower bond default risk and cost of debt capital.

Jorion (2002) examines the VaR presentation of 8 U.S. commercial banks by comparing the trading VaR disclosed by the banks in the sample to the subsequent variability of trading revenues. Results suggest that VaR disclosures are indicative of subsequent variability of trading revenues. Linsmeier, Thornton, Venkatachalam, and Welker (2000) study the effect of FRR No. 48 on trading volume and stock returns. They look at a sample of 222 non-financial firms using sensitivity analysis, $\mathrm{VaR}$, and tabular format for disclosure. They find positive trading volume sensitivity to absolute changes in interest rates, foreign currency exchange rates and commodity prices prior to the effective of FRR No. 48. After FRR No. 48 became effective, they find declines in trading volume sensitivity to these market rates and commodity prices. They conclude that FRR No. 48 provides useful information to investors and thus leads to a reduction in trading volume sensitivity to changes in rates and commodity prices.

Thornton and Welker (2002) study the effect of FRR No. 48 on the stock return sensitivity of firms to changes in commodity prices. Their sample includes only oil and gas firms. They compare the sensitivity of firms' equity price changes to commodity prices, known as beta-shifts, to a matched-sample firms that do not disclose information. They show that the sample of firms that disclose have significantly greater beta-shifts after disclosing than those do not disclose over the same time period. They conclude that FRR No. 48 provides useful information to investors in assessing the relationship between commodity prices and equity price changes.

\section{DATA AND SAMPLE}

To obtain information on how firms report their market risk, we first construct our sample firms by choosing firms that appear in the S\&P 1,500 over the years 2000-2004. The original sample contains 5,304 firm year observations, which is reduced to 4,791 by excluding 513 financial institution observations. We examine 10-Ks for fiscal years 2002-2004 in order to determine disclosure compliance under FRR No. 48; the examination results in the elimination of 576 firm year observations resulting from lack of $10-\mathrm{K}$ information due to mergers, buyouts, or bankruptcies.

Data for estimating the CAPM and three-factor model were collected from Professor French's website (at mba.tuck.dartmouth.edu/pages/faculty/ ken.french/data_library.html). We obtained financial data from Standard and Poor's Compustat databases. We obtained daily stock return information from CRSP. Information on the number of analysts following individual firms was obtained from the $\mathrm{I} / \mathrm{B} / \mathrm{E} / \mathrm{S}$ database. We require firms to have the 
necessary data in the Compustat, CRSP, and IBES database to be included in our sample. Our final sample consists of 3,018 firm year observations.

\section{METHODOLOGY}

\subsection{Measuring firm's risk}

We measure a firm's risk as total risk, cost of equity, measured by the CAPM and the Fama and French three-factor models, and firm specific risk. As in Guay (1999) total risk is measured as the annualized standard deviation of daily stock returns multiplied by $252^{1 / 2}$.

To estimate the cost of equity using the CAPM model, we run the following regression using daily returns to obtain the slopes $b_{i}$

$$
R_{i, t}-R_{f, t}=a_{i}+\sum_{k=-1}^{k=1} b_{i, k}\left(R_{M, t+k}-R_{f, t+k}\right)+e_{i}
$$

where

$R_{i}=$ the return for firm i

$R_{f}=$ the return on one-month Treasury bill

$R_{m}=$ the return of value-weight market portfolio on all NYSE, AMEX, and NASDAQ stocks

Since we use daily returns, we include one lead and one lag terms in addition to the contemporaneous term into the regression to adjusted for biased betas estimated by non-synchronous trading as the method originally proposed by Dimson (1979) and modified by Fowler and Rorke (1983). We obtain the market beta by summing the coefficients estimates on the contemporaneous, one lead, and one lag of the corresponding risk premiums. Following Fama and French (1997) and D'Mello and Shroff (2000), we estimate the cost of equity by substituting the regression slope and arithmetic average daily, $R_{m}-R_{f}$ returns from July 1963 until the year-end date into equation (1), and then multiplying by 252 days.

We also estimate the cost of equity by using the Fama and French three-factor model as there is now a longestablished and well-known literature noting that beta alone cannot explain the cross-sectional variation in average stock returns. For example, Chan, Chen, and Hsieh (1985) found that size captures the default risk that is compensated in returns. Chan and Chen (1991) document that small firms are more sensitive to market conditions, which leads to the differential risk exposures and returns between small and large firms. Fama and French (1992, 1993) demonstrate that three factors: beta, book-to-market ratio, and size, explain the cross-section of returns much better than the beta alone.

To estimate the cost of equity by using the Fama and French three-factor model, we run the following regression by using daily returns to obtain the slopes: $b_{i}, s_{i}, h_{i}$.

$$
R_{i, t}-R_{f, t}=a_{i}+\sum_{k=-1}^{k=1} b_{i, k}\left(R_{M, t+k}-R_{f, t+k}\right)+\sum_{k=-1}^{k=1} s_{i, k} S M B_{t+k}+\sum_{k=-1}^{k=1} h_{i, k} H M L_{t+k}+e_{i}
$$

$R_{i}, R_{m}$, and $R_{f}$ are as defined for equation (1). SMB is the difference in returns between small-stock and large-stock portfolios and $H M L$ is the difference in returns between high book-to-market and low book-to-market portfolios. Following the method described in the CAPM model, we obtain each beta (market, SMB, and HML betas) by summing the coefficients estimates on the contemporaneous, one lead, and one lag of the corresponding risk premiums. We estimate the cost of equity by substituting the regression slopes and arithmetic average daily, $R_{m}-R_{f}$, $S M B$, and $H M L$ returns from July 1963 until the year-end date into equation (2) and then multiplying by 252 days. 
In addition to total risk and the cost of equity, we also estimate risk by using firm specific risk, which is computed as the annualized standard deviation of residuals from the CAPM and three-factor models multiplied by $252^{1 / 2}$.

\subsection{Multivariate framework}

To examine the relationship between the method for reporting market risk exposure and the risk measures, we estimate a fixed-effects model which controls for unobservable industry and time effects. Since Emm, Gay, and Lin (2007) find the tabular method reveals more information to the public, followed by sensitivity, and VaR, we compare other methods to sensitivity to investigate whether other methods decrease or increase the risk more than sensitivity analysis. Following Botosan (1997) and Gebhardt, Lee, and Swaminathan (2001), we specify the relation between the risk and reporting method as follows:

$$
\begin{aligned}
& \text { Risk }_{\mathrm{i}, \mathrm{t}}=\text { Intercept }+\operatorname{VaR}_{i, t}+\text { Tab }_{i, t}+\operatorname{VaR} \& \text { other Method }(s)_{i, t}+\text { Sen \& Tab } b_{i, t}+\text { Leverage }_{i, t}+\text { Book-to-Market }_{i, t}+ \\
& \text { Analysts }{ }_{i, t}+\text { Size }_{i, t}+\text { Industry Dummies }+ \text { Year Dummies }
\end{aligned}
$$

where risk is one of the three measurements: total risk, cost of equity, measured by the CAPM or Fama and French three-factor models, and firm specific risk. We then include several dummy variables for firm reporting methods into equation (3) to investigate the relationship between different reporting methods and firm's risk exposures. VaR in equation (3) is an indicator variable, which is equal to 1 if a firm uses VaR as its disclosure method. Tab indicator variable is equal to 1 if the firm uses tabular format. VaR \& other method(s) indicator variable is equal to 1 if the firm uses $\mathrm{VaR}$ and other method(s). Sen \& Tab indicator variable is equal to 1 if the firm uses sensitivity analysis and tabular. We compare each indicator variable with the intercept which catches our base case, sensitivity.

Leverage, used as a proxy for default risk, is defined as long-term debt plus the current portion of long-term debt divided by total assets. We expect leverage to be positively correlated with the risk measurements. B/M is the book-to-market ratio, used as a proxy for growth opportunities, and is measured by the ratio of book value of equity to the market value of equity. The book-to-market ratio is expected to be positively related to the risk measurements as firms with high book-to-market ratios are expected to have fewer opportunities for growth. We use the number of analysts following the firms to proxy for asymmetric information. Since a higher number of analysts following a firm should reduce the level of asymmetric information, we expect the number of analyst to be negatively related to risk measurements. Size is measured by the natural logarithm of total assets and is expected to be negatively related to the risk measurements. We also include industry, defined at the two-digit SIC code level, and year dummies into equation (3) to control for unobserved industry and time effects.

\section{EMPIRICAL RESULTS}

Table 2 provides descriptive statistics of risk measures for different reporting methods chosen by firms. We find the majority of the firms chose sensitivity followed by tabular. We also find firms choosing VaR have on average lower cost of equity than firms choosing other reporting methods. Firms choosing sensitivity have higher total risk and firm specific risk than firms choosing other reporting methods.

We observe that firms in a particular industry are more likely to select a particular reporting method. For example, $\mathrm{VaR}$ is the most common reporting method for utility industry. Industry may play an important role in firm's reporting method selection. We therefore perform the univariate tests on a matched-pair sample. We match firms using methods other than sensitivity with firms using sensitivity by year, industry, defined at 2-digit SIC code level, and then firm size if there is more than one firm using sensitivity in that particular industry. Table 3 presents the mean and median difference of each risk measure between firms using methods other than sensitivity and firms using sensitivity. We find firms using the combination of VaR and other method(s) (76\% of the firms using VaR and sensitivity in this category) have higher total risk, market risk, and firm specific risk than firms using sensitivity. We also find firms using sensitivity and tabular have higher total risk and firm specific risk than firms using sensitivity alone. 


\section{Table 2 Univariate Statistics of Risk Measures}

This table displays summary statistics of the risk measurements for firms choosing different reporting methods. Risk measures include the total risk, the cost of equity, and firm specific risk. Total risk is the annualized standard deviation of daily stock returns multiplied by $252^{1 / 2}$. Cost of equity is measured by Fama and French three-factor and CAPM models. Firm specific risk is the annualized standard deviation of residuals from the Fama and French three-factor and CAPM models multiplied by $252^{1 / 2}$.

\begin{tabular}{|c|c|c|c|c|c|c|c|c|c|c|c|}
\hline \multirow[b]{3}{*}{ Reporting Methods } & \multirow[b]{3}{*}{ Number of Observations } & \multicolumn{2}{|c|}{ Total Risk } & \multicolumn{4}{|c|}{ Cost of Equity } & \multicolumn{4}{|c|}{ Firm Specific Risk } \\
\hline & & \multirow[b]{2}{*}{ Mean } & \multirow[b]{2}{*}{ Median } & \multicolumn{2}{|c|}{ Three-Factor Model } & \multicolumn{2}{|c|}{ CAPM } & \multicolumn{2}{|c|}{ Three-Factor Model } & \multicolumn{2}{|c|}{ CAPM } \\
\hline & & & & Mean & Median & Mean & Median & Mean & Median & Mean & Median \\
\hline Sensitivity & 2,346 & 0.4144 & 0.3692 & 0.1216 & 0.1039 & 0.1003 & 0.0731 & 0.3466 & 0.3073 & 0.3599 & 0.3171 \\
\hline $\mathrm{VaR}$ & 76 & 0.3317 & 0.2693 & 0.1003 & 0.0791 & 0.0820 & 0.0697 & 0.2735 & 0.2109 & 0.2813 & 0.2157 \\
\hline Tabular & 327 & 0.3987 & 0.3600 & 0.1275 & 0.1100 & 0.1025 & 0.0814 & 0.3316 & 0.3027 & 0.3445 & 0.3105 \\
\hline VaR \& Other Method(s) & 84 & 0.3325 & 0.2660 & 0.1427 & 0.1231 & 0.0913 & 0.0769 & 0.2831 & 0.2153 & 0.2953 & 0.2224 \\
\hline Sensitivity \& Tabular & 185 & 0.3901 & 0.3352 & 0.1334 & 0.1053 & 0.1018 & 0.0754 & 0.3260 & 0.2766 & 0.3387 & 0.2882 \\
\hline
\end{tabular}

Table 3 Matched-Sample Tests of Risk Measures and Reporting Method Chosen

This table shows the mean and median difference of each risk measure for firms choosing reporting methods other than sensitivity over sensitivity based on a matched-pair sample. The matched sample is constructed by matching by year, industry, defined at the two-digit SIC code level, and firm size. Risk measures include the total risk, the cost of equity, and firm specific risk. Total risk is the annualized standard deviation of daily stock returns multiplied by $252^{1 / 2}$. Cost of equity is measured by Fama and French three-factor and CAPM models. Firm specific risk is the annualized standard deviation of residuals from the Fama and French three-factor and CAPM models multiplied by $252^{1 / 2}$. The symbols $*$, $* *$, and $* * *$ indicate statistical significance at the $10 \%, 5 \%$, and $1 \%$ levels, respectively.

\begin{tabular}{|c|c|c|c|c|c|c|c|c|c|c|c|c|c|c|c|c|c|c|c|c|}
\hline \multirow{3}{*}{ Reporting Methods } & \multirow[b]{3}{*}{$\begin{array}{l}\text { Number of } \\
\text { Observations } \\
\end{array}$} & \multicolumn{4}{|c|}{ Total Risk } & \multicolumn{7}{|c|}{ Cost of Equity } & \multicolumn{8}{|c|}{ Firm Specific Risk } \\
\hline & & \multirow[b]{2}{*}{$\begin{array}{l}\text { Mean } \\
\text { Difference }\end{array}$} & \multirow{2}{*}{\multicolumn{2}{|c|}{$\begin{array}{l}\text { Median } \\
\text { Difference }\end{array}$}} & & \multicolumn{4}{|c|}{ Three-Factor Model } & \multicolumn{3}{|c|}{ CAPM } & \multicolumn{4}{|c|}{ Three-Factor Model } & \multicolumn{4}{|c|}{ CAPM } \\
\hline & & & & & & $\begin{array}{l}\text { Mean } \\
\text { Difference }\end{array}$ & & $\begin{array}{l}\text { Median } \\
\text { Difference }\end{array}$ & & $\begin{array}{l}\text { Mean } \\
\text { Difference }\end{array}$ & $\begin{array}{l}\text { Median } \\
\text { Difference }\end{array}$ & & $\begin{array}{l}\text { Mean } \\
\text { Difference }\end{array}$ & & $\begin{array}{l}\text { Median } \\
\text { Difference }\end{array}$ & & $\begin{array}{l}\text { Mean } \\
\text { Difference }\end{array}$ & & $\begin{array}{l}\text { Median } \\
\text { Difference }\end{array}$ & \\
\hline$\overline{\mathrm{VaR}}$ & 76 & -0.0125 & & -0.0458 & $* *$ & -0.0021 & & -0.0127 & & -0.0053 & 0.0005 & & -0.0132 & & -0.0431 & $* *$ & -0.0137 & & -0.0455 & $* *$ \\
\hline Tabular & 304 & -0.0120 & & -0.0099 & & 0.0011 & & 0.0034 & & 0.0022 & 0.0019 & & -0.0127 & & -0.0075 & & -0.0146 & & -0.0121 & \\
\hline VaR \& Other Method(s) & 84 & 0.0727 & $* *$ & 0.0348 & $* * *$ & 0.0212 & $* *$ & 0.0207 & $* *$ & 0.0048 & $* \quad 0.0055$ & & 0.0699 & $* * *$ & 0.0301 & $* * *$ & 0.0714 & $* * *$ & 0.0332 & $* * *$ \\
\hline Sensitivity \& Tabular & 177 & 0.0359 & $* *$ & 0.0211 & $* *$ & -0.0037 & & -0.0006 & & 0.0056 & $* \quad 0.0028$ & $*$ & 0.0301 & $* *$ & 0.0121 & $* *$ & 0.0305 & $* *$ & 0.0129 & $* *$ \\
\hline
\end{tabular}


While the above analysis gives an indication of total risk, cost of equity, and firm specific risk for firms using each method of disclosure, it does not control for firm characteristics that have been empirically shown to affect risk. Table 4 presents results of the regression of total risk on the method of disclosure chosen by the firms. We find that firms using the VaR method as well as the combination of VaR and other method(s) have significantly higher total risk than firms using sensitivity. Most firms that use VaR are utility companies and typically they use derivatives for both trading and non-trading purposes. The resulting information revealed by the firm is often considered to be somewhat confusing and difficult to understand. Investors may thus require a higher return because of difficulty understanding the information provided and because of possible estimation errors resulting from the information. We also find that firms that choose tabular have lower total risk than firms that choose sensitivity analysis but this result is not statistically significant.

Table 4 The Relationship between Total Risk and Reporting Method Chosen

This table presents results for fixed-effects estimation of the total risk on the reporting method chosen by the firms. The dependent variable is total risk which is the annualized standard deviation of daily stock returns multiplied by $252^{1 / 2}$. VaR indicator variable is equal to 1 if a firm chooses VaR. Tabular indicator variable is equal to 1 if a firm chooses tabular. VaR \& Other Method(s) indicator variable is equal to 1 if a firm chooses VaR and other methods. Sensitivity \& Tabular indicator variable is equal to 1 if a firm chooses sensitivity and tabular methods. Leverage is measured by (long-term debt + current portion of long-term debt)/total assets. Book-to-Market Ratio is book value of total equity to market value of total equity. Number of Analysts is the number of analysts following the firm. Size is measured by the natural logarithm of total assets. The regression also includes industry dummies and year dummies. Standard errors are reported in parentheses. The symbols *, **, and *** indicate statistical significance at the $10 \%, 5 \%$, and $1 \%$ levels, respectively.

\begin{tabular}{lc}
\hline Intercept & $0.5366^{* * *}$ \\
VaR indicator variable & $(0.0343)$ \\
& $0.0601 * * *$ \\
Tabular indicator variable & $(0.0180)$ \\
& -0.00665 \\
VaR \& Other method(s) indicator variable & $(0.0092)$ \\
& $0.0639 * * *$ \\
Sensitivity \& Tabular indicator variable & $(0.0178)$ \\
& 0.01351 \\
Leverage & $(0.0117)$ \\
Book-to-Market Ratio & $0.2228 * * *$ \\
Number of Analysts & $(0.0203)$ \\
Size & $0.1290 * * *$ \\
Number of observations & $(0.0094)$ \\
$\mathrm{R}^{2}$ & $0.0041^{* * *}$ \\
\hline
\end{tabular}

Table 5 shows the relationship between the cost of equity and the reporting method chosen by firms. Using the Fama and French three-factor model, we find that firms using VaR and other method(s) to report risk exposures have significantly higher cost of equity than firms using sensitivity analysis. We also find that firms using tabular as well as the combination of sensitivity and tabular methods have a lower (but insignificantly so) cost of equity when estimated by the three-factor model than firms employing sensitivity analysis. 
Table 5 The Relationship between the Cost of Equity and Reporting Method Chosen

This table presents results for fixed-effects estimation of the cost of equity on the method chosen by the firms. The dependent variable is cost of equity measured by Fama-French three-factor model or CAPM. VaR indicator variable is equal to 1 if a firm chooses VaR. Tabular indicator variable is equal to 1 if a firm chooses tabular. VaR \& Other Method(s) indicator variable is equal to 1 if a firm chooses $\mathrm{VaR}$ and other methods. Sensitivity \& Tabular indicator variable is equal to 1 if a firm chooses sensitivity and tabular methods. Leverage is measured by (long-term debt + current portion of long-term debt)/total assets. Bookto-Market Ratio is book value of total equity to market value of total equity. Number of Analysts is the number of analysts following the firm. Size is measured by the natural logarithm of total assets. The regression also includes industry dummies and year dummies. Standard errors are reported in parentheses. The symbols *,**, and *** indicate statistical significance at the $10 \%, 5 \%$, and $1 \%$ levels, respectively.

\begin{tabular}{lcc}
\hline & Three-Factor Model & CAPM \\
\cline { 2 - 3 } Intercept & $0.1960^{* * *}$ & $0.2090^{* * *}$ \\
\cline { 2 - 3 } VaR indicator variable & $(0.0138)$ & $(0.0090)$ \\
& 0.00662 & 0.0002 \\
Tabular indicator variable & $(0.0073)$ & $(0.0048)$ \\
& -0.00156 & 0.00003 \\
VaR \& Other method(s) indicator variable & $(0.0037)$ & $(0.0024)$ \\
& $0.0158^{* *}$ & 0.00115 \\
Sensitivity \& Tabular indicator variable & $(0.0072)$ & $(0.0047)$ \\
& -0.0019 & 0.00158 \\
Leverage & $(0.0047)$ & $(0.0031)$ \\
Book-to-Market Ratio & $0.0759^{* * *}$ & $0.0290^{* * *}$ \\
Number of Analysts & $(0.0082)$ & $(0.0054)$ \\
Size & $0.0373 * * *$ & $0.0108^{* * *}$ \\
Number of observations & $(0.0038)$ & $(0.0025)$ \\
$\mathrm{R}^{2}$ & $-0.0003 * *$ & $0.0008^{* * *}$ \\
\hline
\end{tabular}

Finally, we look at the relationship between firm-specific risk and the methods used by the companies. The results are presented in Table 6. We find that firms using VaR and the combination of VaR and other method(s) have higher firm-specific risk than firms using sensitivity analysis. A firm's total risk includes market risk and firmspecific risk and we find a positive relation between $\mathrm{VaR}$ and total risk and fail to find a significant relation between $\mathrm{VaR}$ and the cost of equity. This result indicates that the higher total risk associated with using VaR is attributable to higher firm-specific risk rather than market-related systematic risk. Firms using VaR and other method(s) have higher total risk, market risk and firm specific risk than firms using sensitivity. Finally, we find firms using tabular have lower firm specific risk than firms using sensitivity although this finding is not statistically significant.

Table 6 The Relationship between Firm-Specific Risk on Method Chosen

This table presents results for fixed-effects estimation of the firm-specific risk on the method chosen by the firms. The dependent variable is firm-specific risk, which is the annualized standard deviation of residuals from the three-factor and CAPM models multiplied by $252^{1 / 2}$. VaR indicator variable is equal to 1 if a firm chooses VaR. Tabular indicator variable is equal to 1 if a firm chooses tabular. VaR \& Other Method(s) indicator variable is equal to 1 if a firm chooses VaR and other methods. Sensitivity \& Tabular indicator variable is equal to 1 if a firm chooses sensitivity and tabular methods. Leverage is measured by (long-term debt + current portion of long-term debt)/total assets. Book-to-Market Ratio is book value of total equity to market value of total equity. Number of Analysts is the number of analysts following the firm. Size is measured by the natural logarithm of total assets. The regression also includes industry dummies and year dummies. Standard errors are reported in parentheses. The symbols *, $* *$, and $* * *$ indicate statistical significance at the $10 \%, 5 \%$, and $1 \%$ levels, respectively. 


\begin{tabular}{lcc}
\hline & Three-Factor Model & CAPM \\
\cline { 2 - 3 } Intercept & $0.4958^{* * * *}$ & $0.5234^{* * *}$ \\
\cline { 2 - 3 } VaR indicator variable & $(0.0318)$ & $(0.0329)$ \\
& $0.0611^{* * *}$ & $0.0623^{* * *}$ \\
Tabular indicator variable & $(0.0167)$ & $(0.0173)$ \\
& -0.00793 & -0.00817 \\
VaR \& Other method(s) indicator variable & $(0.0085)$ & $(0.0088)$ \\
& $0.0626^{* * *}$ & $0.0647 * * *$ \\
Sensitivity \& Tabular indicator variable & $(0.0165)$ & $(0.0171)$ \\
& 0.01179 & 0.01193 \\
Leverage & $(0.0109)$ & $(0.0112)$ \\
Book-to-Market Ratio & $0.2196^{* * *}$ & $0.2287 * * *$ \\
Number of Analysts & $(0.0188)$ & $(0.0195)$ \\
Size & $0.1209 * * *$ & $0.1278^{* * *}$ \\
Number of observations & $(0.0087)$ & $(0.0090)$ \\
$\mathrm{R}^{2}$ & $0.0034 * *$ & $0.0035^{* * *}$ \\
\hline
\end{tabular}

\section{CONCLUSION}

We analyze the association between firm's choice of reporting methods in compliance with FRR No. 48 and total risk, the cost of equity, and firm specific risk. Based on our regression results, we find that firms using VaR have significantly higher total risk and firm specific risk than firms using sensitivity. Firms using the combination of VaR and other method(s) (76\% of the firms use VaR and sensitivity in this category) have higher total risk, market risk, and firm specific risk than firms using sensitivity. Conversely, firms employing tabular generally have (insignificantly) lower total risk, the cost of equity estimated by the Fama and French three-factor model, and firm specific risk than firms using sensitivity. That is because tabular disclosure has to reveal more detail information to enable analysts to derive the alternative sensitivity and VaR metrics. Surprisingly, we fail to find a negative relation between our risk measures and the combination of tabular and sensitivity methods.

Overall, we find firms choosing VaR or VaR and other method(s) have higher risk. However, the causation could be other way around, i.e. firms with higher risk may like to choose a method which reveals less information to the market such as VaR. Testing the causation is beyond the scope of this paper, but it could be an interesting topic for future research.

\section{AUTHOR INFORMATION}

Chen-Miao Lin is Associate Professor of Finance at Clayton State University's School of Business.

Wanda Lee Owens is Assistant Professor of Finance at Clark Atlanta University's School of Business.

James E. Owers is Professor of Finance at Georgia State University's Robinson College of Business.

\section{REFERENCES}

1. Barry, Christopher B., and Stephen J. Brown, Differential information and security market equilibrium, Journal of Financial and Quantitative Analysis, Vol. 20, No. 4, pp. 407-422, 1985.

2. Botosan, Christine A., Disclosure level and the Cost of Equity Capital, The Accounting Review Vol. 72, No. 3, pp. 323-349, 1997.

3. Chan, K.C., Nai-fu Chen, and David A. Hsieh, An exploratory investigation of the firm size effect, Journal of Financial Economics Vol. 14, pp. 451-471, 1985. 
4. Chan, K.C., and Nai-fu Chen, Structural and return characteristics of small and large firms, Journal of Finance, Vol. 46, No. 4, pp. 1467-1484, 1991.

5. Coles, Jeffrey, and Uri Loewenstein, 1988, Equilibrium pricing and portfolio composition in the presence of uncertain parameters, Journal of Financial Economics, Vol. 22, pp. 279-303, 1988.

6. Coles, Jeffrey L., Uri Loewenstein, and Jose Suay, On equilibrium pricing under parameter uncertainty, Journal of Financial and Quantitative Analysis, Vol. 30, No. 3, pp. 347-364, 1995.

7. Culp, Christopher L., and Merton H. Miller, The SEC's costly disclosure rules, The Wall Street Journal (June 25), A14, 1996.

8. Dimson, Elroy, Risk Measurement When Shares Are Subject to Infrequent Trading, Journal of Financial Economics, Vol. 7, pp. 197-226, 1979.

9. D'Mello, Ranjan and Pervin R. Shroff, Equity undervaluation and decisions related to repurchase tender offers: An empirical investigation, Journal of Finance, Vol. 55, No. 5, pp. 2399-2424, 2000.

10. Emm, Ekaterina E., Gerald D. Gay, and Chen-Miao Lin, Choices and Best Practice in Corporate Risk Management Disclosure, Journal of Applied Corporate Finance, Vol. 19, No. 4, pp. 82-94, 2007.

11. Wine, Elizabeth, Disparaged VaR Now May Be the Risk Method of Choice, CFO Alert, Vol. 5, pp. 3, 1998.

12. Fama, Eugene F., and Kenneth R. French, The cross-section of expected stock returns, Journal of Finance, Vol.47, No. 2, pp. 427-465, 1992.

13. Fama, Eugene F., and Kenneth R. French, Common risk factors in the returns on stocks and bonds, Journal of Financial Economics, Vol. 33, pp. 3-56, 1993.

14. Fama, Eugene F., and Kenneth R. French, Industry costs of equity, Journal of Financial Economics, Vol. 43, pp. 153-193, 1997.

15. Fowler, David and C. Harvey Rorke, "Risk measurement when shares are subject to infrequent trading: Comment," Journal of Financial Economics, Vol. 12, pp. 279-283, 1983.

16. Gebhardt, William R., Charles M.C. Lee, and Bhaskaran Swaminathan, Toward an implied cost-of-capital, Journal of Accounting Research, Vol. 39, No. 1; pp. 135-176, 2001.

17. Guay, Wayne R., The impact of derivatives on firm risk: An empirical examination of new derivative users, Journal of Accounting and Economics, Vol. 26, pp. 319-351, 1999.

18. Guo, Hongtao, Quantitative market risk disclosure, bond default risk and the cost of debt: Why value at risk?, Working paper, Baruch College - CUNY, 2003.

19. Jorion, Philippe, How informative are value-at-risk disclosures?, The Accounting Review, Vol. 77, pp. 911931, 2002.

20. Linsmeier, Thomas J., Daniel B. Thornton, Mohan Venkatachalam, and Michael Welker, The effect of mandated market risk disclosures on trading volume sensitivity to interest rate, exchange rate, and commodity price movements, The Accounting Review, Vol. 77, No. 2, pp. 343-377, 2002.

21. Myers, Stewart C. and Majluf, N.S., Corporate financing and investment decisions when firms have information that investors do not have, Journal of Financial Economics, Vol. 13, pp. 187-221, 1984.

22. Securities and Exchange Commission (SEC), Disclosure of accounting policies for derivative financial instruments and derivative commodity instruments and disclosure of quantitative and qualitative information about market risk inherent in derivative financial instruments, other financial instruments, and derivative commodity instruments, Washington, DC, Securities and Exchange Commission, 1997.

23. Thornton, Daniel B., and Michael Welker, The effect of oil and gas producers' FRR No. 48 disclosures on investors on Investors' risk assessments, Journal of Accounting, Auditing, and Finance, Vol. 19, No. 1, pp. 85-114, 2002. 


\section{Exhibit 1 Tabular example: The Kroger Co.}

(Source: The Kroger Co. 10-K filing for the fiscal year ended January 29, 2005)

The tables below provide information about our interest rate derivatives and underlying debt portfolio as of January 29, 2005. The amounts shown for each year represent the contractual maturities of long-term debt, excluding capital leases, and the average outstanding notional amounts of interest rate derivatives as of January 29 , 2005. Interest rates reflect the weighted average for the outstanding instruments. The variable component of each interest rate derivative and the variable rate debt is based on U.S. dollar LIBOR using the forward yield curve as of January 29, 2005. The Fair-Value column includes the fair-value of our debt instruments and interest rate derivatives as of January 29, 2005. Refer to Notes 8, 9 and 10 to the Consolidated Financial Statements:

Expected Year of Maturity

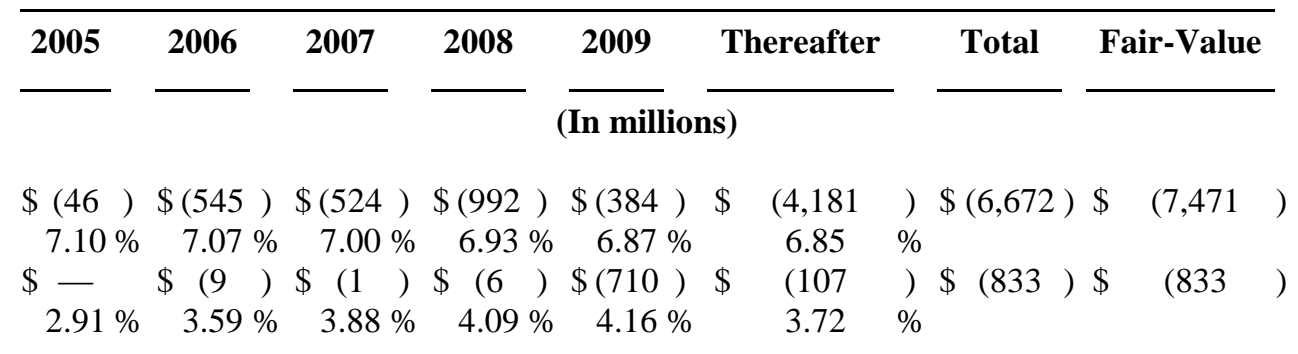

\section{Debt}

Fixed rate

Average interest rate

Variable rate

Average interest rate

Average Notional Amounts Outstanding

Interest Rate Derivatives

Variable to fixed

Average pay rate

Average receive rate

Fixed to variable

Average pay rate

Average receive rate

\begin{tabular}{|c|c|c|c|c|c|c|c|c|c|}
\hline \multicolumn{10}{|c|}{ Average Notional Amounts Outstanding } \\
\hline 2005 & 2006 & 2007 & 2008 & 2009 & \multicolumn{2}{|c|}{ Thereafter } & Total & \multicolumn{2}{|c|}{ Fair Value } \\
\hline \multicolumn{10}{|c|}{ (In millions) } \\
\hline$\$-$ & $\$-$ & $\$-$ & $\$-$ & $\$-$ & $\$$ & - & $\$-$ & $\$$ & - \\
\hline$\$ 1,375$ & $\$ 1,251$ & $\$ 1,050$ & $\$ 363$ & $\$ 300$ & $\$$ & 300 & $\$ 1,375$ & $\$$ & $(11)$ \\
\hline $6.29 \%$ & $6.99 \%$ & $7.06 \%$ & $5.24 \%$ & $4.82 \%$ & & 5.75 & & & \\
\hline $6.98 \%$ & $6.90 \%$ & $6.74 \%$ & $5.38 \%$ & $4.95 \%$ & & $4.95 \quad c$ & & & \\
\hline
\end{tabular}

\section{Exhibit 2 Sensitivity example: Best Buy Co., Inc.}

(Source: Best Buy Co., Inc. 10-K filing for the fiscal year ended February 26, 2005)

Our debt is not subject to material interest-rate volatility risk. The rates on a substantial portion of our debt may be reset, but may not be more than one percentage point higher than the current rates. If the rates on the debt were to be reset one percentage point higher, our annual interest expense would increase by approximately $\$ 4$ million. We do not currently manage the risk through the use of derivative instruments.

We have market risk arising from changes in foreign currency exchange rates as a result of our operations in Canada. At this time, we do not manage the risk through the use of derivative instruments. A $10 \%$ adverse change in the foreign currency exchange rate would not have a significant impact on our results of operations or financial position. 


\section{Exhibit 3 Value at Risk example: The Coca Cola Company}

(Source: The Kroger Co. 10-K filing for the fiscal year ended December 31, 2004)

We monitor our exposure to financial market risks using several objective measurement systems, including value-at-risk models. Our value-at-risk calculations use a historical simulation model to estimate potential future losses in the fair value of our derivatives and other financial instruments that could occur as a result of adverse movements in foreign currency and interest rates. We have not considered the potential impact of favorable movements in foreign currency and interest rates on our calculations. We examined historical weekly returns over the previous 10 years to calculate our value at risk. The average value at risk represents the simple average of quarterly amounts over the past year. As a result of our foreign currency value-at-risk calculations, we estimate with 95 percent confidence that the fair values of our foreign currency derivatives and other financial instruments, over a one-week period, would decline by less than $\$ 17$ million, \$26 million and \$34 million, respectively, using 2004, 2003 or 2002 average fair values and by less than $\$ 18$ million and $\$ 28$ million, respectively, using December 31, 2004 and 2003 fair values. According to our interest rate value-at-risk calculations, we estimate with 95 percent confidence that any increase in our net interest expense due to an adverse move in our 2004 average or in our December 31, 2004 interest rates over a one-week period would not have a material impact on our consolidated financial statements. Our December 31, 2003 and 2002 estimates were not material to our consolidated financial statements. 